\title{
Editorial
}

\section{The leisure sector: Game for a change?}

\section{CALLING TIME ON OLD REGIMES}

This is likely to be an interesting year for the retail and leisure property sector in the UK, not least because of recent and impending legislative changes. 2003 saw the passing of sweeping changes to the licensing laws, ${ }^{1}$ and 2004 is likely to see major changes to the gaming provisions and to planning regulations that affect retail and leisure properties. The cumulative effect of these changes will almost certainly have wide-ranging implications for the leisure and retail property markets. The question is: will the changes, as legislated and proposed, give the industries the flexibility that they need to meet the rapidly changing demands of society? This edition of the Journal provides some insight into both the planning and gaming issues.

Julian Harris reviews the implications for property of the Gaming Bill, if and when it is enacted. In his view, widespread support by the industry and both major political parties provides sufficient incentives to regularise what has become a hopelessly outdated system that runs counter to the needs and demands of the 21 st century. Harris was writing before publication of the Queen's Speech in November 2003, when rumours were circulating that the Bill would be dropped from the parliamentary programme.

However, such fears have not been realised and on 5 February, 2004, the Bill was introduced. ${ }^{2}$

Harris' optimistic view is that the passing of the Bill will lead to the possibility of a more competitive marketplace, in which the number of casinos, their location and their style of offering will all increase, leading to greater participation by the public in gambling, which in turn will result in both increased tax revenue and job creation. This much is indeed likely. However, his opinion that many jobs will be created in places of high unemployment would seem more debatable, given the current pressures that he identifies for operators to open venues, not in depressed areas, but in key population hubs, such as Norwich, which already have successful leisure quarters. Indeed, early evidence is that the 'Vegas' effect may well be associated with extensions to existing leisure and retail schemes, such as Sheffield's Meadowhall. ${ }^{3}$

Richard Negus picks up on another major change for the leisure retailer and one which relates to a situation almost as untenable as the old licensing laws. Under existing UK planning laws the ability to change the use of premises requires express planning permission. 
Some uses are categorised within a Use Classes Order (UCO), while others are sui generis and are regarded as outside any specific use. Under the UCO, change within a class is not deemed to be development and therefore does not require consent; other changes are permitted by virtue of a General Permitted Development Order (GPDO).

The current arrangements, based on the 1987 Order have been regarded widely as unsatisfactory and inflexible as regards their treatment of retail and leisure properties. The reasons for this relate to the very nature of leisure; it is fast-moving and as such requires that the physical format changes too. This much has been acknowledged by government who concluded as early as 1999 that 'perhaps the key feature of commercial leisure is that it undergoes continuous change, which a more affluent public both stimulates and is constantly responding to'. ${ }^{4}$ In illustration, when the current UCO was introduced, the move of food and drink outlets into the high street had hardly begun and the word 'superpub' had not been coined. The leisure industry was, therefore, welcoming of the opportunity provided in 2002 to consult on changes to the UCO as part of the government's wide-ranging review of the UK planning system.

In advance of that consultation, a survey of industry views undertaken on behalf of the Leisure Property Forum (LPF) in 2001 concluded that a new use class of urban entertainment would go a long way to providing the flexibility that the industry needs. They also called for a review of the position in relation to the interface between retail and leisure uses. Relating these findings to the wider planning issues, the LPF's research concluded that there was no doubt but that the system has not proved flexible enough to meet the requirements of the stakeholders consulted. ${ }^{5}$

So will the new proposed UCO lead to a position that safeguards the public and enables leisure operators to respond swiftly and responsibly to the current and future demands? In Negus' view the answer must be 'no'. The new draft UCO, which is likely to be introduced this summer, proposes to further sub-divide the current retail category so that pubs, restaurants and takeaway food outlets, all of which are currently classified as A3, will be separated into three separate sub-categories. However, the distinction between a pub and a restaurant has been blurred for many years and, Negus argues, is growing ever more so with many 'pubs' having a food turnover that outstrips many 'restaurants'. Given this market trend, the proposed distinction seems inappropriate. Indeed, many within the industry had thought that a distinction would be made on the basis of size with 'superpubs', which are the outlets that have caused the most controversy, being singled out for special categorisation. This has proved not to be the case.

The other major change, not chronicled by Negus, is the change to the D class, which covers many leisure uses. Here the creation of a new D3 class to cover nightclubs means that one class of premise 
which derives significant turnover from liquor sales is specifically placed in D class while the others are placed as A class users! It is both regrettable that further consultation with the industry is not to be undertaken and disappointing that the opportunity has not been seized to inject some greater flexibility into the system. Indeed the draft changes could be argued to reduce flexibility.

\section{REGENERATION AND SUSTAINABILITY: CREATING QUARTERS}

One of the main aims of the review of the planning system is to promote sustainability in both social and environmental terms. This is not new; the sustainability movement has been steadily gaining ground over the last decade and this has manifested itself in many ways within the nature and location of property developments. Most notable has been the promotion of mixed-use schemes aimed at urban regeneration. In his contribution, Mark Anders argues that for many mixed-use schemes developers can be tempted to take a formulaic approach with little thought as to the contextual fit of the development to its locality. The fit to the street scene is argued to be vital, with due consideration for the creation of places that work, for as he argues, 'urban regeneration depends on business success'. There is a necessity to adopt a holistic approach and not view a development as a 'pocket' within the wider urban setting; this requires the engagement of stakeholders and a genuine attempt to work with the existing urban grain.

Some of the consequences of adopting a 'pocket approach' to development can be seen in Mike Taylor and Andrew Goodbourn's paper on retail warehousing schemes. This illustrates the relationship between planning policies and the resultant shape of developments. Originally developed in out-of-town or edge-of-town locations, as the impact of the sequential test restricted supply from the mid-1990s, so many schemes are now in need of major investment, including 'tenant engineering', and seem ill-equipped to meet the current in-town mixed-use agenda. Although the investment returns of this sector have remained buoyant compared with other property sectors ${ }^{6}$ the dis-investment of some major players in the market highlighted by Taylor and Goodbourn do point to possible impending problems. The schemes may have been appropriate to the needs of the 1980s, but as retail activity becomes far more integrated with a community-based range of uses, some of them are in danger of looking isolated and socially bleak by comparison.

There are therefore many lessons that developers and the property community can learn by studying the evolution of retail parks. With most commercial schemes built to a design life in excess of 50 years it is critical that the concept is capable of adaptation to meet changing needs. Retail park developments have not always got it right!

Another sector that is currently experiencing some difficulties is the health and fitness sector, where early growth has been followed 
by falling profitability and industry 'shake-out'. Jim Fallon's paper is a timely reminder of the way in which evolution is occurring in the market and the need to recognise that maturity is accompanied by reduction and consolidation of operators. While his paper addresses management, not property, concerns, it is clear that rental levels and yields will come under pressure. Perhaps the time has come to look at the adaptability of some clubs' premises for alternative use!

\section{HOTELS: CREATING AN APPROPRIATE BUSINESS RELATIONSHIP}

Hotels continue to be a sector that features frequently in the journal; this issue is no exception. Both Martin Armitstead and Robert Schlup provide practical and useful insights into hotel management agreements. Schlup's informative paper sets out succinctly some of the issues involved in setting up such agreements from both the owner and the operator perspectives. The key message that the only way to safeguard investment by both parties is by agreeing a deal that recognises and balances the needs of both parties. Although this may seem a truism, it is one that litigation frequently proves is too often forgotten. The keys to this, Schlup suggests, are embedded in fee arrangements, enforceability of contract, controls over concept and brand and in the development of appropriate exit strategies for the owner. He argues it is essential that each party recognises the business needs of the other and particularly for the owner to appreciate that the operator is just that - an organisation whose stated skill base and intention lies in operational, not property, issues.

Although couched in different language, the key message from Armitstead's paper follows a similar theme. He goes further and suggests that in many cases the balance of risk has shifted too far in favour of the owner, as they seek to extract performance from the operator even where the risk transference is not completely put onto the operator, as in the case of a lease. This raises an interesting point, namely that of the inter-relationship of accounting regulations with the attractiveness of any particular structure. As Armitstead points out, although a lease offers the potential for the owner to avoid downside risk, albeit at the expense of participating in upside potential, the US general accounting principles make leases unattractive to owners who are obliged to consolidate liabilities on their balance sheet. With the changes to accounting standards that are being driven by the EU, the same issue is occurring in the UK. And so, both authors advocate the need to take an approach that recognises an equitable sharing of risk and rewards.

\section{REFLECTION}

The Journal has now reached the end of its third volume. During that time many issues have been considered, but recurrent themes 
are apparent, such as planning and finance. One theme that recurs is the need for retail and leisure property to be developed, located and managed such that operators can have the flexibility to both respond to and pre-empt social trends. With this in mind it is little wonder that the industry is looking forward to an era in which gaming and licensing laws and regulation is simplified. It is deeply disappointing that the important planning issue of use class classification is not set to do the same.

\section{References}

1. 2003 saw the passing of the Licensing Act 2003, which introduced sweeping reforms including the introduction of a single premises licence, to be issued by local authorities, and a more flexible approach to opening hours.

2. http://www.culture.gov.uk/global/press_notices/archive_2004/dcms009_04.htm accessed on 23rd February, 2004.

3. Anon (2004) 'Entertainment complex for Sheffield', Leisure Opportunities, No. 358, 17th February, p. 2.

4. Department of the Environment, Transport and the Regions (DETR) (2001) Research Report on Planning for Leisure and Tourism, HMSO, London.

5. Sayce, S. and McIntosh, A. (2001) 'Planning for leisure: Time for a radical re-think or just a slight adjustment?' Paper to the RICS Cutting Edge Conference, Oxford, 5th-7th September.

6. Based on IPD statistics (www.ipdindex.co.uk). 